\title{
Distinct phospholipase A2 enzymes regulate prostaglandin E2 and F2alpha production by bovine endometrial epithelial cells Patricia K Tithof ${ }^{1}$, Mary P Roberts ${ }^{2}$, Wei Guan ${ }^{1}$, Mona Elgayyar ${ }^{1}$ and James D Godkin*2
}

Address: ${ }^{T}$ The University of Tennessee College of Veterinary Medicine, TN, USA and ${ }^{2}$ The University of Tennessee, Department of Animal Science, Knoxville, TN, USA

Email: Patricia K Tithof - ptithof@utk.edu; Mary P Roberts - mrobert5@utk.edu; Wei Guan - wguan@utk.edu; Mona Elgayyar - melgayyar@utk.edu; James D Godkin* - jgodkin@utk.edu

* Corresponding author

Published: 25 April 2007

Reproductive Biology and Endocrinology 2007, 5:16 doi:10.1 186/1477-7827-5-16

This article is available from: http://www.rbej.com/content/5/I/16

(C) 2007 Tithof et al; licensee BioMed Central Ltd.

This is an Open Access article distributed under the terms of the Creative Commons Attribution License (http://creativecommons.org/licenses/by/2.0), which permits unrestricted use, distribution, and reproduction in any medium, provided the original work is properly cited.

\begin{abstract}
Background: The rate-limiting step in prostaglandin (PG) biosynthesis is catalyzed by phospholipase A2 (PLA2) enzymes which hydrolyze arachidonic acid from membrane phospholipids. Despite their importance in uterine PG production, little is known concerning the specific PLA2 enzymes that regulate arachidonic acid liberation in the uterine endometrium. The objectives of this study were to evaluate the expression and activities of calcium-independent Group $\mathrm{VI}$ and Group IVC PLA2 (PLA2G6 and PLA2G4C) and calcium-dependent Group IVA PLA2 (PLA2G4A) enzymes in the regulation of bovine uterine endometrial epithelial cell PG production.
\end{abstract}

Methods: Bovine endometrial epithelial cells in culture were treated with oxytocin, interferon-tau and the PLA2G6 inhibitor bromoenol lactone, alone and in combination. Concentrations of PGF2alpha and PGE2 released into the medium were analyzed. Western blot analysis was performed on cellular protein to determine the effects of treatments on expression of PLA2G4A, PLA2G6 and PLA2G4C. Group-specific PLA2 activity assays were performed on cell lysates following treatment with oxytocin, interferon-tau or vehicle (control), alone and in combination. To further evaluate the role of specific PLA2 enzymes in uterine cell PG biosynthesis, cells were transfected with cDNAs encoding human PLA2G6 and PLA24C, treated as described above and PG assays performed.

Results: Constitutive cell production of PGF2alpha was about two-fold higher than PGE2. Oxytocin stimulated production of both PGs but the increase of PGF2alpha was significantly greater. Interferon-tau diminished oxytocin stimulation of both PGs. The PLA2G6 inhibitor, bromoenol lactone, abolished oxytocin-stimulated production of PGF2alpha. Treatments had little effect on PLA2G4A protein expression. In contrast, oxytocin enhanced expression of PLA2G6 and this effect was diminished in the presence of interferon-tau. Expression of PLA2G4C was barely detectable in control and oxytocin treated cells but it was enhanced in cells treated with interferon-tau. Oxytocin stimulated PLA2 activity in assays designed to evaluate PLA2G6 activity and interferon-tau inhibited this response. In assays designed to measure PLA2G4C activity, only interferon-tau was stimulatory. Cells overexpressing PLA2G6 produced similar quantities of the two PGs and these values were significantly higher than PG production by non-transfected cells. Oxytocin stimulated production of both PGs and this response was inhibited by interferon-tau. Bromoenol lactone inhibited oxtocin stimulation of PGF2alpha production but stimulated PGE2 production, both in the absence and presence of oxytocin. Cells over-expressing PLA2G4C produced more PGE2 than PGF2alpha and interferon-tau stimulated PGE2 production. 
Conclusion: Results from these studies indicate that oxytocin stimulation of uterine PGF2alpha production is mediated, at least in part, by up-regulation of PLA2G6 expression and activity. In addition to its known inhibitory effect on oxytocin receptor expression, interferon-tau represses oxytocin-stimulated PLA2G6 expression and activity and this contributes to diminished PGF2alpha production. Furthermore, endometrial cell PGE2 biosynthesis was associated with PLA2G4C expression and activity and interferon-tau was stimulatory to this process.

\section{Background}

In domestic ruminants (sheep, cattle, goats) estrous cyclicity is regulated by uterine $\mathrm{PGF}_{2 \alpha}$-induced demise of the corpus luteum $[1,2] . \mathrm{PGF}_{2 \alpha}$ is released from endometrial luminal and superficial glandular epithelium in an episodic fashion toward the end of the estrous cycle. Oxytocin (OT), of neurohypophyseal and luteal origin, is believed to bind endometrial OT receptors and initiate pulsatile $\mathrm{PGF}_{2 \alpha}$ secretion, which in turn, stimulates release of luteal OT and creates a positive feedback loop that results in several series of pulses of short duration which are effective in causing luteolysis $[3,4]$. During early pregnancy, the conceptus protein interferon tau (IFNT) binds to endometrial receptors and attenuates episodic PGF $2 \alpha$ secretion, thereby rescuing the CL from regression and maintaining progesterone production [5-7].

Release of arachidonic acid (AA) from membrane glycerophospholipids is catalyzed by phospholipase $\mathrm{A}_{2}$ enzymes and is considered the rate-limiting step in PG biosynthesis [8]. Released $\mathrm{AA}$ is then metabolized to $\mathrm{PGG}_{2}$ by a cyclooxygenase reaction and then to $\mathrm{PGH}_{2}$ by a peroxidase reaction, both mediated by cyclooxygenase (COX) 1 and/or -2. Terminal PG synthases, which exhibit tissuespecific distribution, then convert $\mathrm{PGH}_{2}$ to bioactive PGs including $\mathrm{PGF}_{2 \alpha}, \mathrm{PGE}_{2}, \mathrm{PGD}_{2}$ and $\mathrm{PGI}_{2}$.

Although PLA2 activation catalyzes the rate-limiting step in PG biosynthesis, most investigations of the mechanisms and regulation of uterine PG production have focused on the activation and expression of down-stream enzymes, such as the cyclooxygenases and PG synthases. The few studies [9-12] that have examined the role of PLA2 in uterine PG production in domestic ruminants have focused on a single enzyme, cPLA2 $\alpha$ (Group IVA PLA2 or PLA2G4A). Surprisingly, none of these studies identified consistent changes in expression of protein or mRNA for PLA2G4A in association with alterations in PG production. In contrast, non-specific PLA2 inhibitors significantly diminished both basal and agonist-induced PG production [10-12].

Mammalian cells contain structurally diverse PLA2 enzymes that differ in their location and regulation [reviewed in [13] and [14]]. At least 14 groups, and numerous subgroups, of PLA2s have been classified. These groups include four main families of PLA2s, the low molecular weight secretory PLA2s, the cytosolic PLA2G4s, the calcium-independent PLA2G6s and the platelet activating factor (PAF) acid hydrolases (PLA2G7 and PLA2G8). The intracellular PLA2G4 and PLA2G6 enzymes are specifically important in the regulation of PG biosynthesis because their sites of action are the perinuclear membranes where down-stream AA metabolizing enzymes (cyclooxygenases and PG synthases) reside.

The first cytosolic PLA2 discovered was PLA2G4A and it has received, by far, the most attention. It is a 749 amino acid, $85 \mathrm{kDa}$ protein that migrates at $100-112 \mathrm{kDa}$ in polyacrylamide gels. It is present in the cytosol of resting cells and upon activation by a variety of agonists, undergoes $\mathrm{Ca}^{++}$-directed translocation to perinuclear membranes. The $\mathrm{N}$-terminal $\mathrm{Ca}^{++}$-dependent lipid binding (CaLB) or C2 domain is essential for membrane association and responsible for translocation in response to stimuli that increase intracellular calcium [14+]. Gene disruption studies have indicated an important role for PLA2G4A in normal fertility, eicosanoid production from inflammatory cells, brain injury and allergic response in mice [15-17]. Mice with a null mutation for the gene have fewer implantation sites, smaller litters and fail to undergo labor at term.

Several additional Group IV PLA2 enzymes have been cloned recently, including IVB, IVC, IVD, IVE and IVF [1820]. Of these enzymes, IVC (PLA2 $\gamma$ ) is of interest because it is constitutively associated with membranes, the major site of prostaglandin biosynthesis, lacks the C2 domain and does not require $\mathrm{Ca}^{++}$for activation. Although first associated with membrane remodeling, recent studies demonstrate that PLA2G4C functions as a signaling PLA2 linked to $\mathrm{PGE}_{2}$ production [21].

In the literature, the term calcium-independent PLA2, has generally referred to the Group 6 family of PLA2 enzymes [13], despite the fact that Group $4 \mathrm{C}$ is $\mathrm{Ca}^{++}$-independent as well. Two distinct subclasses of Group 6 have been identified and characterized, 6A (also referred to as iPLA2 and $\mathrm{PPLA} 2 \mathrm{~B}$ ) and 6B (iPLA2 $\gamma$ ). More recently several novel iPLA2s have been identified, including iPLA $2 \delta$, iPLA $2 \varepsilon$, iPLA2 $\zeta$ and iPLA2 $\eta[22]$. These novel iPLA2 family members display primarily lysophospholipase, triacylglycerol lipase and/or transacylase activities rather than PLA2 activity. Group 6A has been cloned and characterized in 
several species and cell types [23-25]. It has a mass of 85$88 \mathrm{kDa}$, contains 7-8 terminal ankyrin repeats, and a consensus lipase motif. Several splice variants of the enzyme are expressed yielding multiple molecular weight isoforms [25]. Recently, expression of a $50 \mathrm{kDa}$ Group 6 enzyme in rat myometrium was associated with agonistinduced uterine contractions [26].

All PLA2 enzymes catalyze the hydrolysis of the sn-2 ester bond of phospholipids to produce free fatty acids and lsophospholipid $[13,14]$. A distinguishing characteristic of PLA2G4A is that it exhibits greater selectivity for lipids containing arachidonic acid than other cytosolic PLA2s. For this reason, PLA2G4A has been the enzyme primarily associated with direct generation of arachidonic acid and initiation of the eicosanoid cascade. However, PLA2G4C [21] and PLA2G6 [32,33] have been associated with agonist-stimulated arachidonic acid release and eicosanoid biosynthesis. In addition, it has been shown that PLA2G6 may mediate release of arachidonic acid directly by hydrolysis of arachidonate-containing plasmalogens or through an indirect, multi-step process involving hydrolysis of diacyl lipids to arachidonyl lysophosphatidylcholine [34].

The objectives of the present study were to investigate the expression and activities of Group 4A, 4C and 6A PLA2 enzymes in association with $\mathrm{PGF}_{2 \alpha}$ and $\mathrm{PGE}_{2}$ production in bovine endometrial epithelial cell cultures. Results indicate that in addition to PLA2G4A, PLA2G6 and PLA2G4C contribute to regulation of uterine cell PG production and these latter two enzymes are activated in response to oxytocin and INFT, respectively.

\section{Methods \\ Materials}

Bovine endometrial epithelial (BEE) cells were from Cell Applications, Inc. (Catalog no. B932-05, San Diego, CA). Dulbecco minimum essential medium (MEM), Ham F12, Hank's buffered saline solution (HBSS), gentamicin, oxytocin, PDBu, bovine serum albumin, fetal bovine serum, horse serum, aprotinin, leupeptin and pepstatin were from Sigma Chemical Co (St Louis, MO). Enzyme Immunoassay kits for $\mathrm{PGE}_{2}$ (catalog no. 900-001) and $\mathrm{PGF}_{2 \alpha}$ (catalog no. 901-069) were from Assay Designs, Inc (Ann Arbor, MI). 1-palmitoyl-2-(1-14C) arachidonylphosphotidylcholine (14C-AA-PC), 1-palmitoyl-2-(1-14C) oleoyl-phosphotidylcholine $\left({ }^{14} \mathrm{C}-\mathrm{OA}-\mathrm{PC}\right)$ and 1 -palmitoyl-2-(1-14C) linoleoyl-phosphotidylcholine (1-14C-LA) were from Amersham Corp (Arlington Heights, IL). Group 4A PLA 2 antibody (SC-454) was from Santa Cruz Biotechnology, Inc (Santa Cruz, CA), Group 6 PLA $_{2}$ antibody (Anti-iPLA,$\#$ 07-169) was from Upstate Cell Signaling Solutions (Lake Placid, NY) and the anti-Group 4C was a gift from Dr. C.C. Leslie (University of Colorado,
Boulder, CO). Recombinant ovine IFN $\tau$ (antiviral activity, $1 \times 10^{8} \mathrm{U} / \mathrm{mg}$ ) was donated kindly by Dr. F.W. Bazer (Texas A\&M University, College Station, TX). The PLA2G6 inhibitor, bromoenol lactone (BEL) and the PLA2G4 and PLA2G6 inhibitor methyl arachidonyl fluorophosphonate (MAFP) were from Cayman Chemical (Ann Arbor, $\mathrm{MI}$ ) and the PLA2G4A inhibitor, pyrrolidine-1 (PYR-1), was a gift from Dr. Michael Gelb (University of Washington, Seattle WA). Tissue culture plasticwares were from Benton Dickinson and Co. (Franklin Lakes, NJ). Unless noted otherwise, additional chemicals were from Sigma Chemical Corp.

\section{Cell culture}

Bovine endometrial epithelial cells were cultured and propagated by procedures suggested by Cell Applications, Inc. According to the distributor, the cells, isolated from epithelium of bovine endometrium and cryopreserved at second passage, can be cultured and propagated for at least 10 doublings. Briefly, cells were seeded in tissue culture dishes of the appropriate size for each experiment (see below) at a concentration of $0.5 \times 10^{5}$ cells per $\mathrm{ml}$ in culture medium (40\% Hams F-12, 40\% MEM, $200 \mathrm{U}$ insulin $/ \mathrm{L}, 50 \mu \mathrm{g} / \mathrm{ml}$ gentamicin, 10\% FBS and 10\% horse serum) at $37^{\circ} \mathrm{C}$ in a humidified atmosphere of $95 \%$ air and $5 \% \mathrm{CO}_{2}$ and culture medium was changed every other day.

\section{PG assays}

Cells were grown to $~ 90 \%$ confluence in 6-well plates, washed three times with HBSS and cultured for $6 \mathrm{~h}$ in unsupplemented Hams F-12/MEM with the following treatments: control, oxytocin (OT, $0.1 \mu \mathrm{M})$, IFNT (50 ng/ $\mathrm{ml})$, the PLA2G6 inhibitor BEL $(7.5 \mu \mathrm{M})$, IFNT + OT and BEL + OT. Vehicles, Hams F-12/MEM for OT and IFNT, and DMSO for the inhibitor were added to each well. Treatments were performed in triplicate and the experiment was repeated $(n=6)$. At the end of the incubation period, medium was harvested and stored frozen at $20^{\circ} \mathrm{C}$. Prostaglandin $\mathrm{F}_{2 \alpha}$ and $\mathrm{E}_{2}$ assays were performed with enzyme immunoassay kits from Assay Designs, Inc., according to supplier's instructions. Inter- and intraassay coefficients of variation $(n=12)$ were $9 \%$ and $11 \%$, respectively.

\section{Western blot analysis}

Western blot analysis was performed as described previously (27). Briefly, cells grown to confluence in $60 \mathrm{~mm}$ dishes were treated with vehicle (control), OT and IFNT (50 ng and $1000 \mathrm{ng}$ ), alone and in combination for $6 \mathrm{~h}$ as described above. Treatments were performed in triplicate. Cells were lysed in RIPA buffer (50 mM Tris- $\mathrm{HCl}, 150 \mathrm{mM}$ $\mathrm{NaCl}, 1 \%$ SDS, $0.5 \%$ sodium deoxycholate, $1 \mathrm{mM}$ DTT, $100 \mu \mathrm{M}$ PMSF, $1 \% \mathrm{NP}-40$, and $1 \times$ protease inhibitor cocktail (Roche Applied Science, Indianapolis, IN), soni- 
cated and centrifuged (10,000 g, 20 minutes). Supernatants from each treatment were combined and $30 \mu \mathrm{g}$ protein from each treatment was subjected to $10 \%$ SDSpolyacrylamide gel electrophoresis and transferred onto nitrocellulose membranes. Non-specific binding sites were blocked with $5 \%$ non-fat dry milk and membranes were incubated with antibodies to PLA2G4A, PLA2G4C, and PLA2G6 in 1:800, 1:400 and 1:1000 dilutions, respectively, overnight at $4^{\circ} \mathrm{C}$. Membranes were rinsed 3 times and protein bands were visualized using an enhanced fluorescent reagent (ECL Western blotting detection kit, Amersham Biosciences, Piscataway, NJ).

\section{Over expression of PLA2G4C and PLA2G6A in BEE cells} Full-length cDNAs encoding human PLA2G4C (accession number XM 009119) and PLA2G6A (accession number

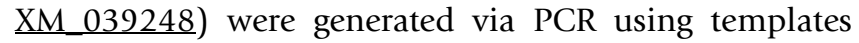
from human coronary artery endothelial cells. Primers for PLA2G4C were: upstream 5'CCG CAG TGC ACC ATG GGA AGC TC 3', downstream 5'C TCC CAG CTA CCC GGC CAC GTT C 3'. Primers for PLA2G6A were: upstream 5' G GCG GGC ACC GCC ACT GGA GC 3', downstream 5 'GAA TGC CCC ATG CGT CTC CCA G $3{ }^{\prime}$. The cDNAs were ligated into the PCR2.1-TOPO plasmid vector of the TA cloning system (Invitrogen Corp, Carlsbad, CA), subcloned and sequenced. Homologies with the human PLA2G4C and PLA2G6A were $>99 \%$. The cDNAs were ligated into the PCR3.1 expression vector (Invitrogen Corp, Carlsbad, CA). Plasmids were incorporated into BEE cells using the Superfect ${ }^{\mathrm{TM}}$ (Qiagen Inc, Valencia, CA) transfection system according to manufacturers' instructions. Over expression of PLA2G4C and PLA2G6 was confirmed by Western blot analysis. Cells transfected with PLA2G6 were treated for $6 \mathrm{~h}$ with vehicle (control), IFNT $(50 \mathrm{ng} / \mathrm{ml})$, OT $(0.1 \mu \mathrm{M})$, OT and IFNT, BEL $(7.5 \mu \mathrm{M})$, and BEL and OT. Cells transfected with PLA2G4C were treated for $6 \mathrm{~h}$ with vehicle (control), IFNT $(50 \mathrm{ng} / \mathrm{ml})$, OT $(0.1 \mu \mathrm{M})$, OT and IFNT. Treatments were performed in triplicate and repeated $(n=6)$. Prostaglandin $E_{2}$ and $F_{2 \alpha}$ assays were performed as described above.

\section{PLA $A_{2}$ activity in cellular homogenates}

$\mathrm{PLA}_{2}$ assays were performed on cellular lysates, as described previously [27], following treatment of intact cells. Briefly, cells were grown to $80 \%$ confluence. Treatments, OT, IFNT, alone and in combination, were applied for $3 \mathrm{~h}$. Some treatments included the inhibitors, BEL, MAFP and PYR-1, which were applied 30 min before other treatments. Concentrations of treatments were as listed above unless otherwise noted. Experiments were performed in triplicate and repeated twice. At the end of the incubation period, cells were washed with $\mathrm{Ca}^{++}$-free PBS containing $5 \mathrm{mM}$ EGTA and $1 \mathrm{mM}$ phenylmethyl-sulfonylchloride (PMSF), lysed in homogenizing buffer (50 $\mathrm{mM}$ Tris $\mathrm{HCl}, \mathrm{pH} 7.4,0.5 \mathrm{mM}$ dithiothreitol, $20 \%$ glyc- erol, $1 \mu \mathrm{g} / \mathrm{ml}$ leupeptin, $10 \mu \mathrm{g} / \mathrm{ml}$ aprotinin, $1 \mathrm{mM}$ PMSF and sonicated two times for 10 seconds on ice. The substrates 1-palmitoyl-2-[arachidonoyl] phophatidylcholine (cold AA-PC) and 1-palmitoyl-2-[arachidonoyl-1-14 C] phosphatidylcholine $\left({ }^{14} \mathrm{C}-\mathrm{AA}-\mathrm{PC}\right), 1$-palmitoyl-2-[linoleoyl] phosphatidylcholine (cold LA-PC), 1-palmitoyl-2[linoleoyl-1-14C] phosphatidlycholine $\left({ }^{14} \mathrm{C}-\mathrm{LA}-\mathrm{PC}\right), 1$ palmitoyl-2-[oleoyl] phosphatidylcholine (OA-PC) and 1-palmitoyl-2-[oleoyl-1-14 $\mathrm{C}$ ] phosphatidylcholine $\left({ }^{14} \mathrm{C}\right.$ -

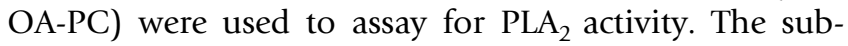
strates were dried under nitrogen and resuspended by sonication in assay buffer (10 mM Hepes, pH 7.5) to a final optimum concentration of cold to radiolabeled substrate as determined previously. In preliminary studies, calciumdependent and - independent activities were identified. Calcium-dependent activity (primarily PLA2G4A) assays were performed with AA-PC and ${ }^{14} \mathrm{C}-\mathrm{AA}-\mathrm{PC}$ in the presence of $5 \mathrm{mM} \mathrm{CaCl}_{2}$ and calcium-independent activity (primarily PLA2G6 and PLA2G4C) assays were performed using the same substrates but in the absence of $\mathrm{CaCl}_{2}$ and the presence of EGTA ( $5 \mathrm{mM}$ ). Assays optimized for identification of PLA2G4C utilized OA-PC and ${ }^{14} \mathrm{C}-\mathrm{OA}-\mathrm{PC}$ in the absence of calcium (this enzyme is arachidonoyl-nonselective and $\mathrm{Ca}^{++}$-independent) and assays optimized for PLA2G6 utilized LA-PC and ${ }^{14} \mathrm{C}-\mathrm{LA}-\mathrm{PC}$ in the absence of $\mathrm{Ca}^{++}$and presence of $400 \mu \mathrm{M}$ Triton-X and $0.8 \mathrm{mM}$ ATP which enhance the activity of this enzyme [28]. Experiments were terminated by addition of chloroform-methanol, 2:1 (v/v), the chloroform layer was extracted and lipids separated by thin-layer chromatography (hexane: diethyl ether: glacial acetic acid, 7:3:0.2). Lipids were visualized with $\mathrm{I}_{2}$ vapor, the zones corresponding to fatty acid and phospholipids were excised and radioactivity determined by scintillation counting.

\section{Statistical analysis}

Data for PG production and PLA2 activity are presented as means +/- SEM and subjected to least squares analysis of variance using the general linear models procedure of the Statistical Analysis System (SAS Institute, Cary, NC). Sources of variance included experiments, treatments and their interactions. Individual comparisons of means were made using Student-Neuman-Keuls test in which the independent variables were the treatments and the dependent variables were the levels of PG or PLA2 activity produced. Differences were considered statistically significant when $\mathrm{P}<0.05$.

\section{Results}

\section{Prostaglandin production}

The effects of treatment on $\mathrm{PGF}_{2 \alpha}$ and $\mathrm{PGE}_{2}$ production by bovine endometrial epithelial cells are illustrated in Figure 1. In the absence of stimulation (control), cells produced about twice the amount of $\mathrm{PGF}_{2 \alpha}$ as $\mathrm{PGE}_{2}$ (p < 0.05). Oxytocin stimulated $\mathrm{PGF}_{2 \alpha}$ and $\mathrm{PGE}_{2}$ production 
about five fold and two fold, respectively. Alone, IFNT had little effect on the production of either PG but it significantly inhibited the stimulatory effect of oxytocin on $\mathrm{PGF}_{2 \alpha}$ production and numerically diminished $\mathrm{PGE}_{2}$ production. Alone, BEL, the PLA2G6 inhibitor [30], had little effect on $\mathrm{PGF}_{2 \alpha}$ production but enhanced $\mathrm{PGE}_{2}$ synthesis. In combination with oxytocin, BEL completely abolished the stimulatory effect of oxytocin on $\mathrm{PGF}_{2 \alpha}$ but not $\mathrm{PGE}_{2}$ production.

Prostaglandin production by BEE cells transfected with PLA2G6 plasmids, is illustrated in Figure 2. Overexpression (OE) of PLA2G6 in BEE cells significantly increased constitutive production of $\mathrm{PGF}_{2 \alpha}$ and $\mathrm{PGE}_{2}$ compared to non-transfected cells (compare values in Fig. 2 to Fig. 1). Oxytocin significantly increased production of both PGs by about 50\% compared to non-stimulated OE (control) cells. Alone, IFNT had little effect on PG production but it diminished, significantly, the stimulatory effect of oxytocin when the treatments were combined. The PLA2G6 inhibitor BEL, alone, did not affect $\mathrm{PGF}_{2 \alpha}$ production compared to controls, but it abolished oxytocin stimulation of $\mathrm{PGF}_{2 \alpha}$ production when the two treatments were combined. Conversely, BEL dramatically enhanced $\mathrm{PGE}_{2}$ production, alone and in combination with oxytocin.
Figure 3 illustrates results of prostaglandin production by BEE cells overexpressing the PLA2G4C enzyme. Production of both PGs was significantly enhanced compared to non-transfected cells and the increase in $\mathrm{PGE}_{2}$ was significantly greater than that of $\mathrm{PGF}_{2 \alpha}$. Alone, IFNT had little effect on $\mathrm{PGF}_{2 \alpha}$ production but significantly stimulated $\mathrm{PGE}_{2}$ production. Oxytocin stimulated production of both PGs compared to control PLA2G4C transfected cells and the effect on $\mathrm{PGE}_{2}$ production was greater. When combined, IFNT diminished oxytocin stimulation of $\mathrm{PGF}_{2 \alpha}$ but $\mathrm{PGE}_{2}$ production values were similar to oxytocin and IFNT treatments, alone.

\section{PLA $A_{2}$ protein expression}

Western blot analysis of cellular proteins from BEE cells demonstrated that the PLA2G4A antibody recognized a protein which migrated at $110 \mathrm{kD}$, the PLA2G6 antibody recognized protein which migrated at $85 \mathrm{kD}$ and the PLA2G4C antibody cross-reacted with a protein migrating at $61 \mathrm{kD}$ (Figure 4). Two isoforms of PLA2G6 were identified, a major band at $85 \mathrm{kd}$, and a minor band of slightly greater mass. Similar result have been observed previously and likely the result of alternative splicing of the PLA2G6 transcript resulting in multiple isoforms of the enzyme [25]. Cells were treated for $6 \mathrm{~h}$ with vehicle (control, lane 1), IFNT (50 ng, lane 2), IFNT(1000 ng, lane 3), oxy-

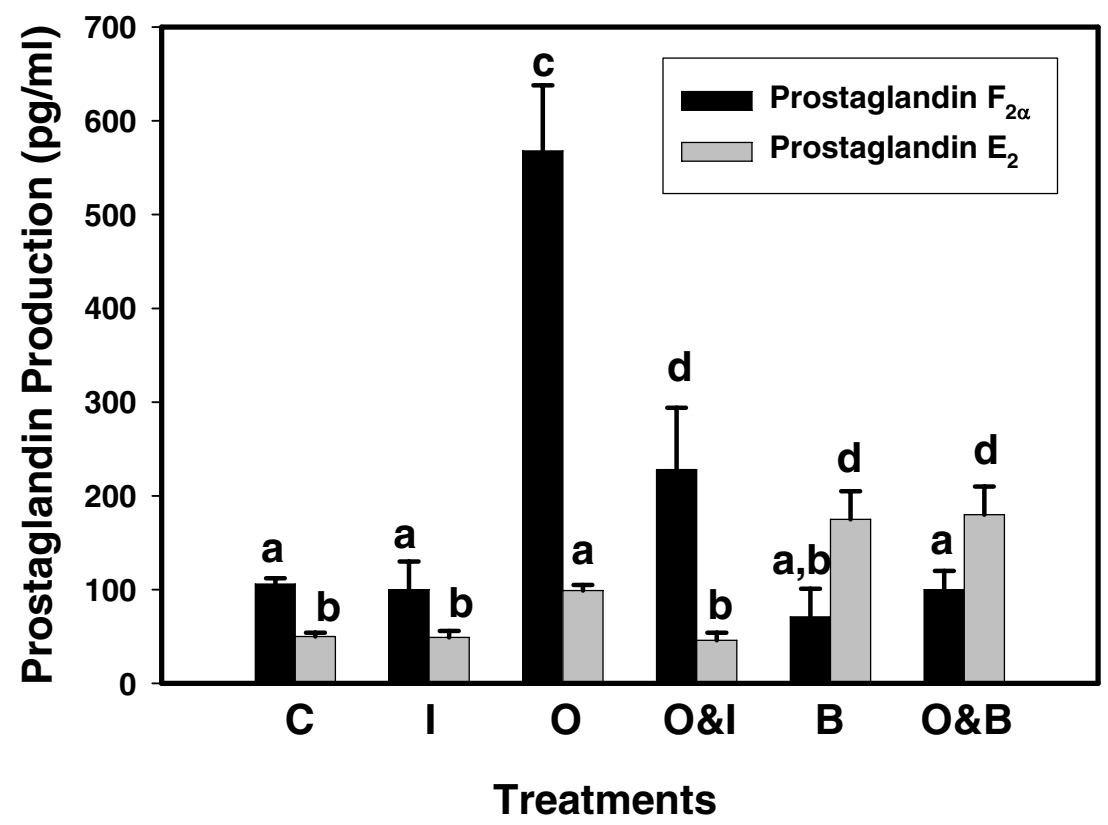

Figure I

Prostaglandin $\mathbf{F}_{2 \alpha}$ and $\mathbf{E}_{\mathbf{2}}$ production by BEE cells. Cell culture medium was harvested $6 \mathrm{~h}$ after addition of treatments and concentrations of PGs were analyzed by ELISA. Treatments included, Control, C; IFNT, I; Oxytocin, O; Oxytocin and IFNT, O\&I, Bromoenol lactone, B; and Oxytocin and Bromoenol lactone, O\&B. Treatments were performed in triplicate and repeated $(n=6)$. Data are expressed as means and SEM. Columns with different superscripts are significantly different $(p<$ $0.05)$. 


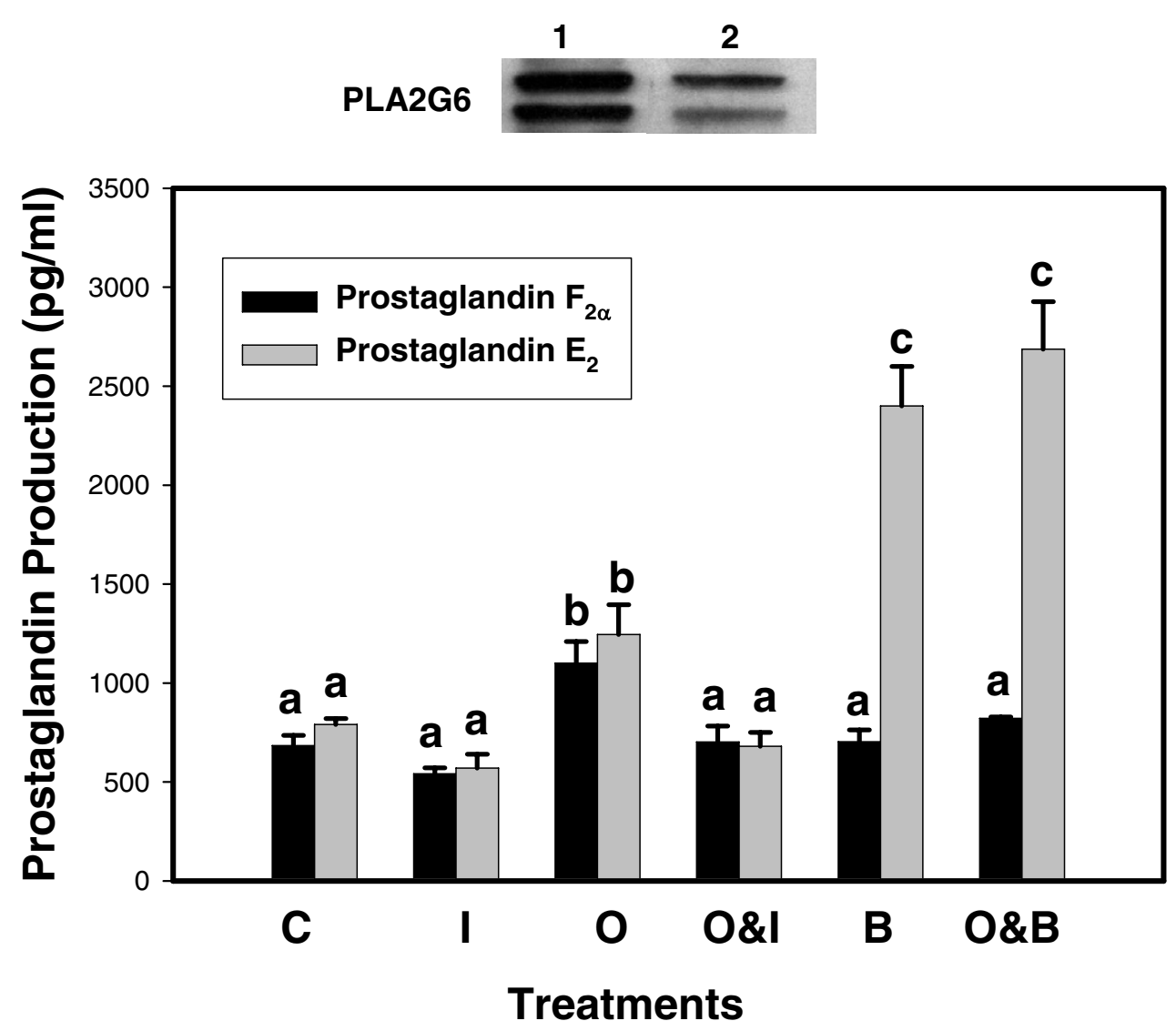

Figure 2

Prostaglandin $F_{2 \alpha}$ and $E_{2}$ production by BEE cells over-expressing PLA2G6. Culture medium from BEE cells, transfected with PLA2G6 cDNA, was harvested $6 \mathrm{~h}$ after exposure to treatments and concentrations of PGs were analyzed by ELISA. Treatments included Control, C; IFNT, I; Oxytocin, O; :Oxytocin and IFNT, O\&I, Bromoenol lactone, B; Oxytocin and Bromoenol lactone, B\&O. Treatments were performed in triplicate and repeated $(n=6)$. Data are expressed as means and SEM. Columns with different superscripts are significantly different $(p<0.05)$. Western blot at top of figure compares PLA2G6 expression in transfected cells (lane I) and non-transfected cells (lane 2).

tocin $(0.1 \mu \mathrm{M}$, lane 4$)$, oxytocin $(0.1 \mu \mathrm{M})$ plus 50 ng IFNT (lane 5$)$ and oxytocin $(0.1 \mu \mathrm{M})$ plus $1000 \mathrm{ng}$ IFNT (lane 6) to determine the effects of these treatments on $\mathrm{PLA}_{2}$ isotype expression. As shown in Figure 4A, expression of PLA2G6 (Fig 4A) was influenced by treatments. Oxytocin up-regulated PLA2G6 (Fig 4A, lane 4) and this effect was diminished by IFNT treatments (Fig 4A, lanes 5 and 6). Expression of PLA2G4C (Fig 4B) was barely detectable, except when cells were treated with IFNT, which enhanced expression of the enzyme (Fig 4B, lanes 2, 3, 5 and 6). In contrast, PLA2G4A was expressed at similar levels in all treatment groups (Figure 4C).

\section{PLA $A_{2}$ activity assays}

Cell lysate $\mathrm{PLA}_{2}$ assays were performed in an attempt to identify enzyme-specific activities based on differences in substrate selectivity, $\mathrm{Ca}^{++}$requirements, cofactor-dependent activity amplification and specific inhibitor effects.
Figure 5 illustrates that BEE cells exhibit both $\mathrm{Ca}^{++}$ dependent activity (primarily PLA2G4A) and $\mathrm{Ca}^{++}$-independent activity (primarily PLA2G6 and PLA2G4C). Calcium-dependent activity was inhibited by PYR-1, a PLA2G4A-specific inhibitor [31], MAFP, a G4 and G6 inhibitor [30] and BEL (a PLA2G6-specific inhibitor) due to the fact that both G4C and G6 PLA 2 enzymes do not require $\mathrm{Ca}^{++}$for activity but function in its presence. Calcium-independent activity was inhibited by BEL and MAFP, but not PYR-1, which inhibits only the $\mathrm{Ca}^{++}$ dependent PLA2G4A.

Figure 6 depicts the results of $\mathrm{PLA}_{2}$ assays designed specifically to evaluate PLA2G6 activity in homogenates of BEE cells following treated of intact cells for $3 \mathrm{~h}$ with or without oxytocin in the presence and absence of IFNT, BEL or PYR-1. Oxytocin significantly stimulated PLA2G6 activity and IFNT inhibited this response. Inhibition of oxytocin 


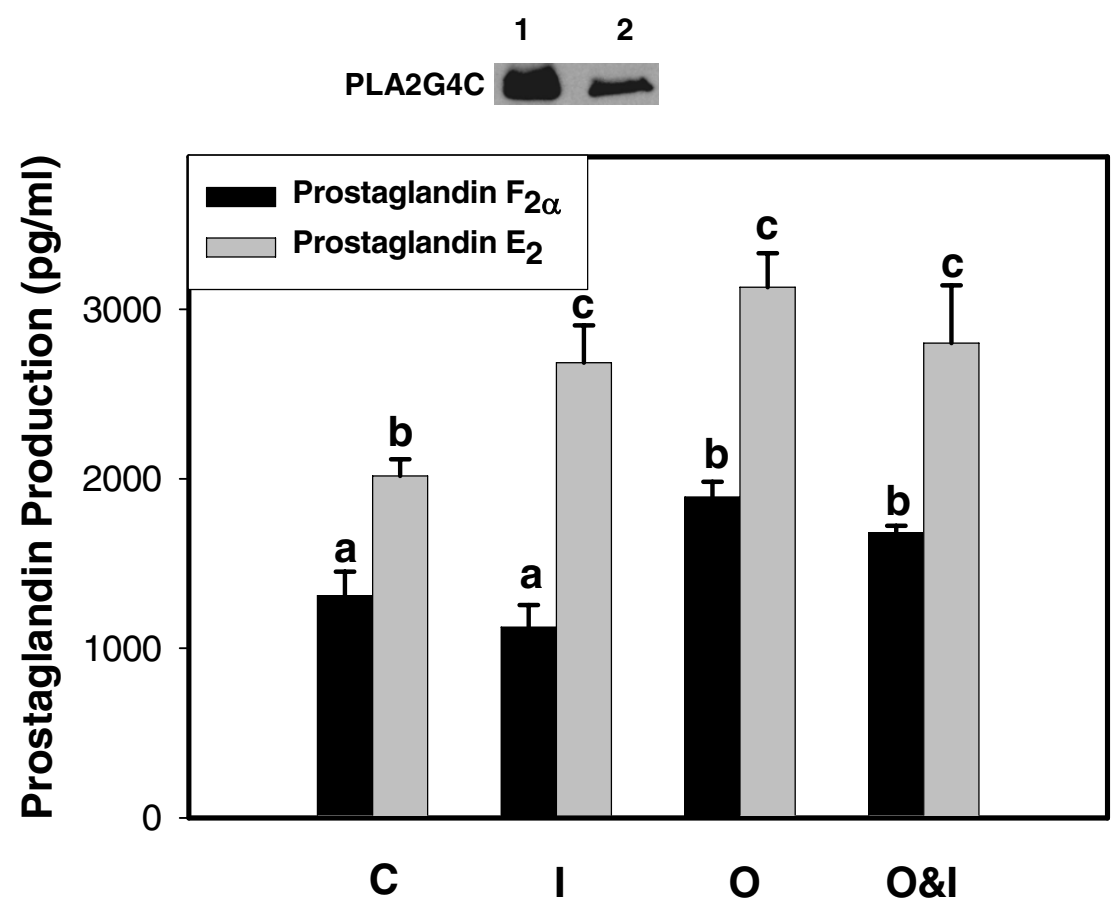

Figure 3

Prostaglandin $F_{2 \alpha}$ and $E_{2}$ production by BEE cells over-expressing PLA2G4C. Culture medium from BEE cells, transfected with PLA2G4C cDNA, was harvested $6 \mathrm{~h}$ after exposure to treatments and concentrations of PGs were analyzed by ELISA. Treatments included Control, C; IFNT, I; Oxytocin, O, Oxytocin and IFNT, O\&I. Data are expressed as means and SEM. Treatments were performed in triplicate and repeated $(n=6)$. Columns with different superscripts are significantly different $(p<0.05)$. Western blot at top of figure compares PLA2G4C expression in transfected cells (lane I) and non-transfected cells (lane 2).

stimulation of activity by BEL but not PYR-1 confirms that PLA2G6 activity was measured.

Results from PLA 2 assays designed to measure PLA2G4C activity are illustrated in Figure 7 . BEE cells were treated for 3 h with vehicle (control), oxytocin, BEL, PYR-1, MAFP or IFNT. Considerable constitutive activity was present and this activity was inhibited by the G4 and G6 PLA2 inhibitor MAFP but not the G6-specific inhibitor BEL or the G4A-specific inhibitor PYR-1. Group IVC PLA2 activity was significantly stimulated by IFNT.

\section{Discussion}

Prostaglandins are essential regulators of numerous reproductive processes but, despite their primary involvement in fertility regulation, the cellular and molecular mechanisms that regulate prostaglandin production are poorly understood. The rate-limiting step in prostanoid biosynthesis is at the level of PLA2 enzymes but, surprisingly, little is known concerning the regulatory function of specific PLA2 isoforms that mediate arachidonic acid release and are likely coupled to downstream enzymes that synthesize the different PGs in reproductive tissues. Although in vivo studies may provide the most complete physiological conditions in which to evaluate uterine biology, they are not best suited for analysis of some cellular mechanisms involving biochemical pathways. For this reason, we turned to in vitro cell cultures to evaluate PLA2 regulation of PG biosynthesis. To our knowledge, this is the first study to demonstrate that expression and activity of the calcium-independent PLA2G6 and PLA2G4C in endometrial epithelial cells are differentially regulated by oxytocin and IFNT, resulting in altered prostaglandin biosynthesis.

Three lines of evidence support the concept that PLA2G6 is involved in oxytocin stimulation of endometrial $\mathrm{PGF}_{2 \alpha}$ production. One, the PLA2G6 inhibitor BEL abolished oxytocin stimulation of $\mathrm{PGF}_{2 \alpha}$ production. Two, oxytocin increased expression of PLA2G6 as determined by Western blot analysis; and three, PLA2G6-specific activity was increased by oxytocin and this response was blocked by BEL. Similarly, the results indicate that IFNT diminished oxytocin stimulated PLA2G6 expression (Figure 4A, Western blot analysis) and activity (Figure 6) resulting in diminished $\mathrm{PGF}_{2 \alpha}$ production (Figure 1). These results do not exclude PLA2G4A from playing a role in oxytocin- 


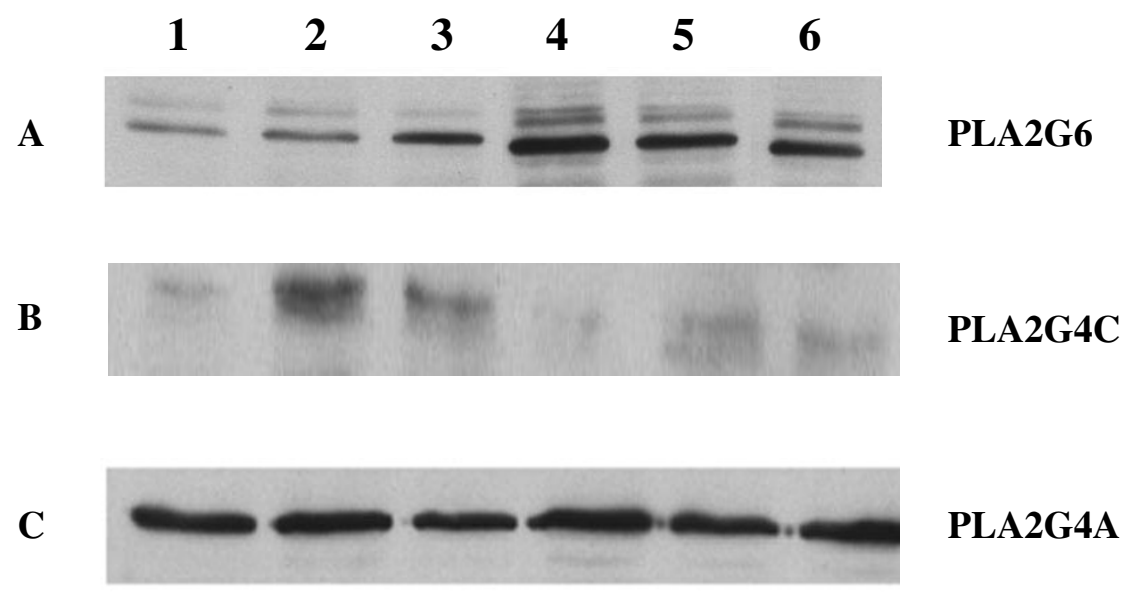

\section{Figure 4}

Oxytocin and interferon-tau differentially regulate expression of PLA2 enzymes. BEE cells were treated for $6 \mathrm{~h}$ with vehicle (control, lane I), 50 ng IFNT (lane 2), I000 ng IFNT (lane 3), oxytocin (lane 4), oxytocin plus 50 ng IFNT (lane 5 ), and oxytocin plus $1000 \mathrm{ng}$ IFNT (lane 6). Western blot analyses were performed on cellular proteins using antibodies against A, PLA2G6; B, PLA2G4C and C, PLA2G4A as described in the Methods.

stimulated uterine PG production. Indeed, PLA2G4A knock-out mice fail to initiate labor at term. On the other hand, the results presented may help to explain why previous studies [10-12] failed to identify consistent changes in PLA2G4A expression or activity in response to oxytocin.

The observation that BEL inhibition of PLA2G6 activity blocked oxytocin stimulation of $\mathrm{PGF}_{2 \alpha}$ production led to studies that examined the effects of PLA2G6 overexpression on PG production. Cells that over expressed this enzyme produced significantly more $\mathrm{PGF}_{2 \alpha}$ and $\mathrm{PGE}_{2}$ than control non-transfected cells. Oxytocin increased production of both PGs and IFNT diminished these responses. As expected, BEL inhibited oxytocin-stimulated $\mathrm{PGF}_{2 \alpha}$ production. In contrast, BEL, alone or in combination with oxytocin, greatly enhanced $\mathrm{PGE}_{2}$ production. Increased $\mathrm{PGE}_{2}$ production in response to $\mathrm{BEL}$ was also observed in non-transfected BEE cells and, in previous studies [29], we have repeatedly observed stimulation of $\mathrm{PGE}_{2}$ production by BEL in primary cultures of ovine endometrial epithelial cells. Although BEL is a relatively selective PLA2 inhibitor at the concentration used, it has also been shown to inhibit $\mathrm{Mg}^{++}$-dependent phosphatidic acid phosphohydrolase (PAP-1), an enzyme that catalyzes the dephosphorylation of phosphatidic acid to diacylglycerol [30]. Change in PAP-1 activity would not explain the observed increase in $\mathrm{PGE}_{2}$. Alteration of the $\mathrm{PGE}_{2}: \mathrm{PGF}_{2 \alpha}$ ratios could be affected at the level of the PG synthases. To our knowledge, there is no evidence that BEL affects PGE synthase expression or activity. In addition, studies in human monocytes [32] and rat mesangial cells [33] have demonstrated that stimulation of the arachadonic acid/ PGE cascade is mediated by PLA2G6 activation and BEL inhibited agonist-stimulated $\mathrm{PGE}_{2}$ production in these cells. These data would argue against a stimulatory activity of BEL on $\mathrm{PGE}_{2}$ synthase.

Functional coupling between different PLA2 isoforms, COX-2 and specific PG synthases has been suggested as a regulatory mechanism of prostanoid biosynthesis in a variety of cell types [36-38]. Individual isoforms, coupled to specific signaling stimuli, may act on different cellular pools of arachidonic acid at different locations in membranes. Inhibition of PLA2G6 with BEL blocked oxytocin stimulated $\mathrm{PGF}_{2 \alpha}$ production but stimulated $\mathrm{PGE}_{2}$ production. One possible explanation for the differential effects of BEL on PG production may be that PLA2G6 is functionally coupled to $\mathrm{PGF}_{2 \alpha}$ production which is stimulated by oxytocin and inhibition of PLA2G6 blocks this response. Conversely, inhibition of PLA2G6 may be permissive to activation of other PLA2 isoforms, such as PLA2G4C, which may be functionally coupled to $\mathrm{PGE}_{2}$ production. Clearly, confirmation of this hypothesis will require additional studies.

During early pregnancy in ruminants, IFNT not only suppresses episodic release of $\mathrm{PGF}_{2 \alpha}$ from the endometrium, but it also enhances production of $\mathrm{PGE}_{2}$ [39-41]. $\mathrm{PGE}_{2}$ has been proposed to have multiple roles in the maintenance of early pregnancy, including action as a luteotrophic or luteoprotective signal and as a mediator of endometrial receptivity $[38,39]$. The mechanism by which IFNT upregulates $\mathrm{PGE}_{2}$ production is unknown but Arosh et al. 


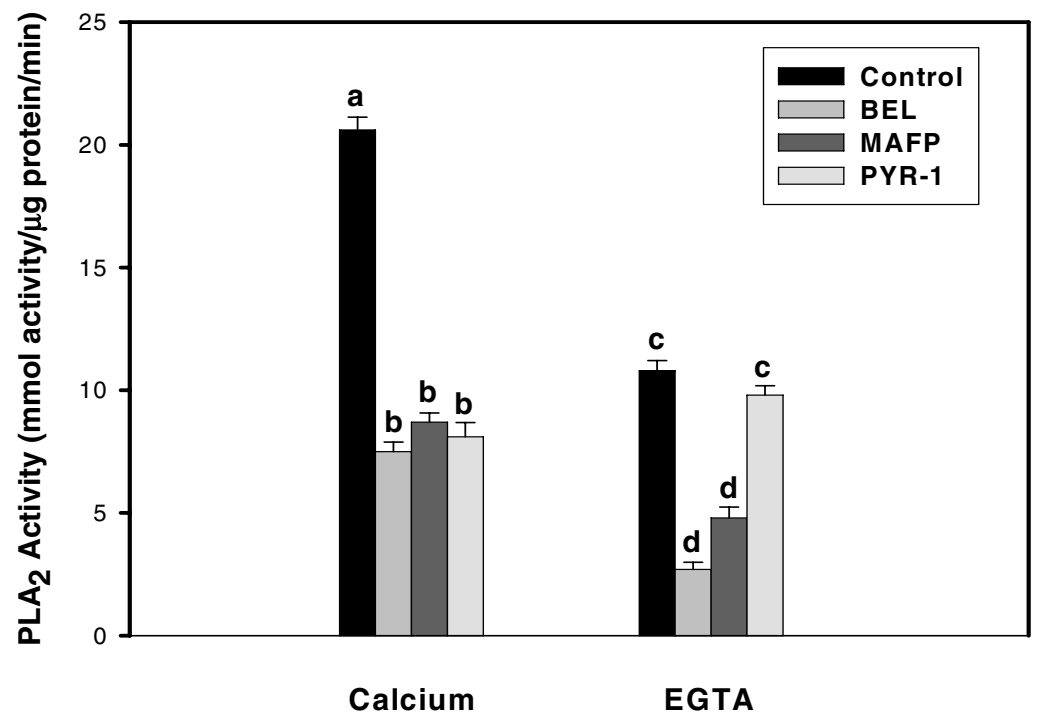

\section{Figure 5}

BEE cells exhibit both $\mathrm{Ca}^{++}$-dependent and $\mathrm{Ca}^{++}$-independent PLA2 activities. PLA2 activity assays were performed on cellular lysates following treatment of intact cells, as described in the Methods. $\mathrm{Ca}^{++}$-dependent PLA2 activity assays were performed with AA-PC and ${ }^{14} \mathrm{C}-\mathrm{AA}-\mathrm{PC}$ in the presence of $5 \mathrm{mM} \mathrm{CaCl}$ and $\mathrm{Ca}^{++}$-independent assays were performed using the same substrates but in the absence of $\mathrm{CaCL}_{2}$ and the presence of $5 \mathrm{mM}$ EGTA. Treatments included the PLA2G6 inhibitor BEL, the PLA2G4 and PLA2G6 inhibitor MAFP and the PLA2G4A inhibitor PYR-I. Data from columns with different superscripts are significantly different $(P<0.05)$.

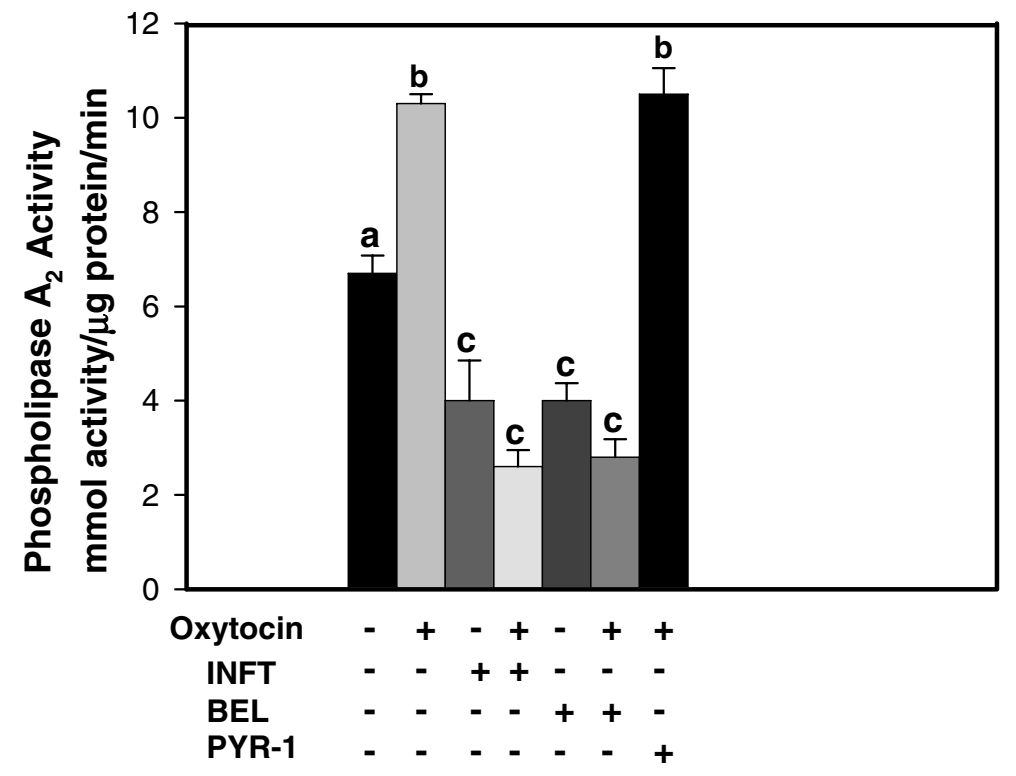

\section{Figure 6}

Oxytocin stimulated PLA2G6 activity is blocked by IFNT. BEE cells were treated for $3 \mathrm{~h}$ with vehicle control, oxytocin, IFNT, BEL or PYR-I, alone or in combination. The symbols, + and -, indicate the presence or absence of treatments, respectively. PLA2G6 activity assays were performed on cellular lysates as described in the Methods. Inhibition of activity by BEL but not PYR-I demonstrates that PLA2G6 activity was measured. Columns with different superscripts are significantly different $(p<0.05)$. 


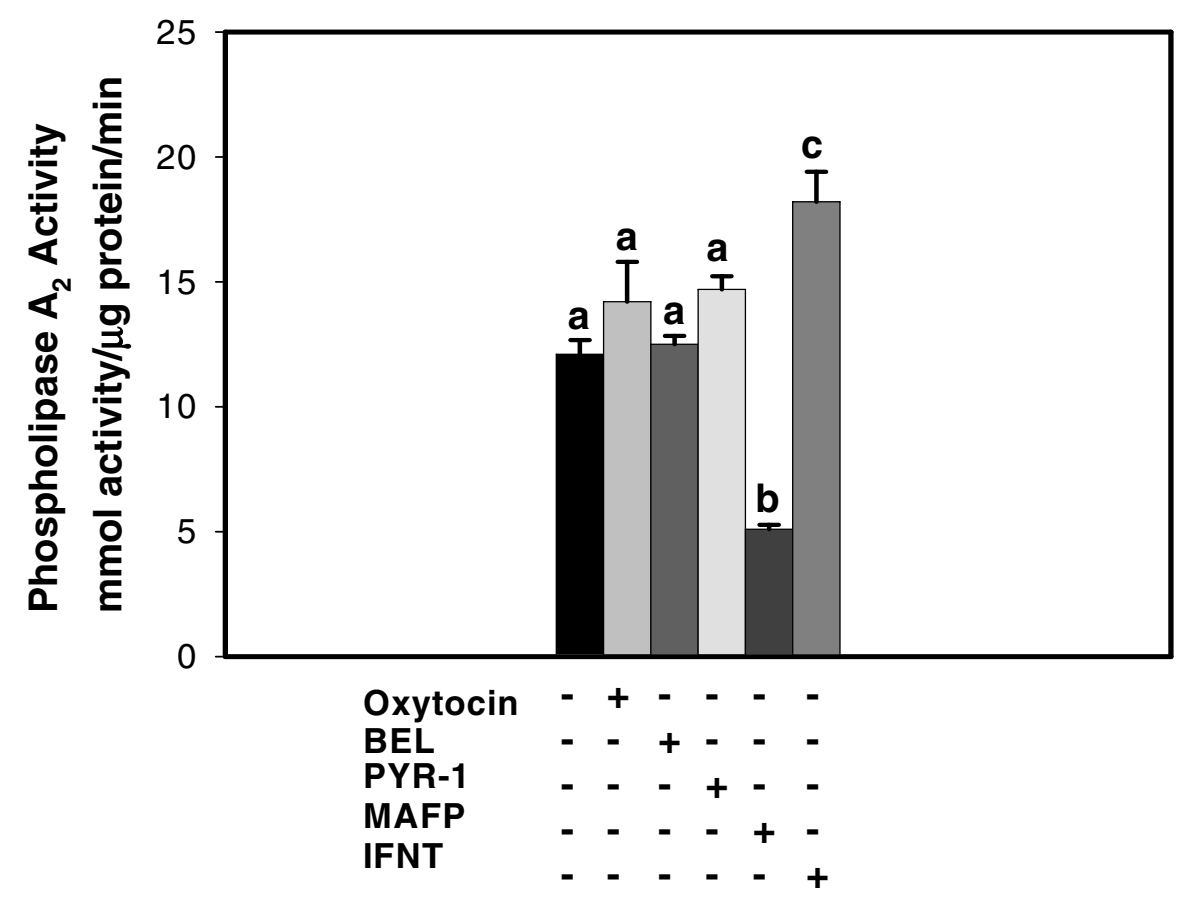

\section{Figure 7}

PLA2G4C activity is enhanced by IFNT but not oxytocin. BEE cells were treated for $3 \mathrm{~h}$ with vehicle control, oxytocin, BEL, PYR-I, MAFP or IFNT. The symbols, + and -, indicate the presence or absence of treatments, respectively. PLA2G4C activity assays were performed on cellular lysates as described in the Methods. Inhibition of activity by MAFP but not PYR-I or BEL demonstrates that PLA2G4C activity was measured. Columns with different superscripts are significantly different $(P<$ 0.05).

[39] have shown that it does not enhance PGE $_{2}$ synthase expression in bovine endometrium. We propose IFNT regulation of $\mathrm{PGE}_{2}$ production involves, at least in part, modulation of expression and activity of a PLA2 isoform. Results from cell-free PLA 2 assays and Western blot analysis demonstrated that PLA2G4C activity and expression were up-regulated by IFNT. Over expression of PLA2G4C in BEE cells increased production of both PGs but the increased $\mathrm{PGE}_{2}$ was significantly greater than the increased $\mathrm{PGF}_{2 \alpha}$. Treatment of these cells with IFNT significantly stimulated $\mathrm{PGE}_{2}$ production. Together, these results indicate that the PLA2G4C enzyme is coupled to $\mathrm{PGE}_{2}$ production and this activity is positively regulated by IFNT.

Luteolysis, resulting from episodic secretion of $\mathrm{PGF}_{2 \alpha^{\prime}}$ is acknowledged, generally, to be orchestrated progesterone, estradiol and oxytocin acting through their respective endometrial receptors $[1,2]$. During early pregnancy, IFNT diminishes expression of the estrogen receptor- alpha and the oxytocin receptor thereby blocking the OT-PGF ${ }_{2 \alpha}$ feedback loop and preventing luteolysis [41,42]. There can be little doubt that diminished oxytocin receptor expression contributes to early pregnancy maintenance in ruminants, but some studies have indicated that IFNt-mediated repression of oxytocin receptors is not absolute. For example, Burgess et al. [43] demonstrated that PGFM release, following bolus inter-arterial oxytocin injection, was similar in day 14-16 cyclic and pregnant ewes, indicating that some oxytocin receptor activity remains during early pregnancy; and Mann et al. [44] demonstrated in cattle that oxytocin receptor concentrations were not a limiting factor in oxytocin stimulated PGFM release. Based on the results from the present study, it is suggested that in addition to repressing oxytocin receptor expression, IFNT diminishes oxytocin stimulation of PLA2G6-linked PGF $2 \alpha$ production and enhances PLA2G4C-linked PGE 2 production.

\section{Conclusion}

Together, the data indicate that uterine PG production is regulated, at least in part, by the expression and activity of PLA2 enzymes and that specific PLA2 isotypes may regulate the production of specific PGs.

\section{Competing interests}

The author(s) declare that they have no competing interests. 


\section{Authors' contributions}

PKT designed and supervised completion of the PLA2 assays, Western blot analyses, over-expression studies and contributed to the drafting of the manuscript. MPR performed the PG assays. WG performed the over-expression studies and $\mathrm{PLA}_{2}$ assays. ME perform the Western blot analyses. JDG designed the study, overall, and drafted the manuscript. All authors read and approved the final version of the manuscript.

\section{References}

I. McCracken JA, Custer EE, Lamsa JC: Luteolysis: a neuroendocrine mediated event. Physiol Rev 1999, 79:263-323.

2. Silvia WJ, Lewis GS, McCracken JA, Thatcher WW, Wilson L Jr: Hormonal regulation of uterine secretion of prostaglandin $\mathbf{F}_{2 \alpha}$ during luteolysis in ruminants. Biol Reprod 1991, 45:655-663.

3. Kindahl H, Lindell JO, Edqvist LE: Release of prostaglandin $\mathbf{F} \mathbf{2}_{\alpha}$ during the oestrous cycle. Acta Vet Scand I98I, 77:143-I58.

4. Schramm W, Bovaird L, Glew ME, Schramm G, McCracken JA: Corpus luteum regression induced by ultra-low pulses of prostaglandin F2. Prostaglandins 1983, 26:347-364.

5. Robert RM: Conceptus interferons and maternal recognition of pregnancy. Biol Reprod 1989, 40:449-452.

6. Bazer FW, Spencer TE, Ott TL, Johnson HM: Cytokines and pregnancy recognition. In Immunobiology of Reproduction Edited by: Hunt JS. Springer-Verlage New York, Inc; 1994:37-56.

7. Godkin JD, Smith SE, Johnson RD, Dore JJE: The role of trophoblast interferons in the maintenance of early pregnancy in ruminants. Am / Reprod Immunol 1997, 37:137-143.

8. Capper EA, Marshall LA: ammalian phospholipases $\mathbf{A}_{2}$ : mediators of inflammation, proliferation and apoptosis. Prog Lipid Res 200I, 40:167-197.

9. Graf GA, Burns PD, Silvia WJ: Expression of a cytosolic phospholipase $A_{2}$ by ovine endometrium on days II-14 of simulated oestrous cycle. J Reprod Fertil 1999, I | 5:357-363.

10. Lee J-S, Silvia W]: Cellular mechanisms mediating the stimulation of ovine endometrial secretion of prostaglandin $F_{2 a}$ in response to oxytocin: Role of phospholipase $\mathbf{A}_{2}$. J Endocrinol 1994, 141:49|-496.

11. Burns PD, Graf GA, Hayes SH, Silvia WJ: Cellular mechanism by which oxytocin stimulates uterine PGF $_{\mathrm{a} 2}$ synthesis in bovine endometrium: Role of Phospholypases $\mathbf{C}$ and $\mathbf{A}_{2}$. Dom Anim Endocrinol |997, | 4:|8|-|9|.

12. Burns PD, Graf GA, Hayes SH, Silvia WJ: Effect of oxytocin on expression of cytosolic phospholipase $A_{2}$ mRNA and protein in ovine endometrial tissue in vivo. Domest Anim Endocrinol 2000, 19:P237-246.

13. Six DA, Dennis EA: The expanding superfamily of phospholipase $\mathbf{A}(2)$ enzymes: classification and charterization. Biochim Biophys Acta 2000, 1488: I-19.

14. Leslie CC: Properties and regulation of cytosolic phospholipase $\mathbf{A}_{2}$. J Biol Chem 1997, 272:16709-167I2.

15. Bonventre JV, Huang Z, Reza Taheri M, O'Leary E, Moskowitz MA, Sapirstein $A$ : Reduced fertility and postischaemic brain injury in mice deficient in cytosolic phospholipase $\mathbf{A}_{2}$. Nature 1997, 390:622-625.

16. Uozumi N, Kume K, Nagase T, Nakatani N, Ishii S, Tashiro F, Komagata Y, Maki K, Ikuta K, Ouchi Y, Miyazaki J, Shimizu T: Role of cytosolic phospholipase A2 in allergic response and parturition. Nature 1997, 390:618-621.

17. Sapirstein A, Bonventure JV: Specific physiological roles of cytosolic phospholipase $A_{2}$ as defined by gene knockouts. Biochima Biophys Acta 2000, I 488: 139-I48.

18. Underwood KW, Song C, Kriz RW, Chang XJ, Knopf JL, Lin LL: A novel calcium-independent phospholipase $A_{2}, C_{P L A}$ that is prenylated and contains homology to CPLA 2 . J Biol Chem 1998, 273:21926-21932

19. Song C, Chang XJ, Bean K, Proia MS, Knopt JL, Kriz RW: Molecular characterization of cytosolic phospholipase A2- $\beta$. J Biol Chem 1999, 274: 17063-17067.
20. Ohto T, Uozumi N, Hirabayashi T, Shimuzu T: Identification of novel cytosolic phospholipase $A_{2} \mathbf{s}$ which form a gene cluster with cPLA B. J Biol Chem 2005, 26:24576-24583.

2I. Murakami M, Masuda S, Kudo I: Arachidonate release and prostaglandin production by group IVC phospholipase $\mathbf{A}_{2}$. Biochem J 2003, I 5:695-702.

22. Jenkins CM, Mancuso DJ, Yan W, Sims HF, Gibson B, Gross RW: Identification, cloning expression and purification of three novel human calcium-independent phospholipase A2 family members possessing triacylglycerol lipase and acylglycerol transacylase activities. J Biol Chem 2004, 279:48968-48975.

23. Winstead MV, Balsinde J, Dennis EA: Calcium-independent phospholipase $\mathbf{A}_{2}$ : structure and function. Biochem Biophys Acta 2000, 1488:28-39.

24. Ackermann EJ, Kempner, Dennis EA: $\mathbf{C a}^{2}+$ independent cytololic phospholipase $A_{2}$ from macrophage-like $\mathbf{P}_{388 D}$ cells. Isolation and characterization. J Biol Chem 1999, 269:9227-9233.

25. Larsson PK, Claesson HE, Kennedy BP: Multiple splice variants of the human calcium-independent phospholipase $A_{2}$ and their effect on enzyme activity. J Biol Chem 1998, 273:207-2I4.

26. Brant K, Guan W, Tithof P, Caruso RL: Gestation age-related increase in $50 \mathrm{kDa}$ rat uterine calcium-independent phospholipase A2 expression influences uterine sensitivity to polychloronated biphenyl stimulation. Biol Reprod 2006, 74:874-880.

27. Tithof PK, Elgayyar M, Cho Y, Guan W, Fisher AB, Peters-Golden M: Polycyclic aromatic hydrocarbons present in cigarette smoke cause endothelial cell apoptosis by a phospholipase $A_{2}$-dependent mechanism. FASEB J 2002. published on-line I 0.1 096/fj.0I-0909fje.

28. Yang HC, Mosior M, Johnson CA, Chen Y, Dennis EA: Group specific assays that distinguish between four major types of mammalian phospolipase $\mathbf{A}_{2}$ enzymes. Anal Biochem 1999, 269:278-288.

29. Ochs G, Roberts M, Tithof $P$, Godkin J: PLA2 regulation of uterine prostaglandin synthesis [abstract]. Biol Reprod 2006:34.

30. Balsinde J, Balboa MA, Insel PA, Dennis EA: Regulation and inhibition of phospholipase $A_{2}$. Annu Rev Pharmacol Toxicol 1999, 39:175-189.

3I. Ghomaschi F, Stewart A, Hefner Y, Ramanadhams S, Turk J, Leslie CC, Gelb MH: A pyrrolidine-based specific inhibitor of cytosolic phospholipase $A_{2}$ blocks arachidonic acid release in a variety of mammalian cells. Biochim Biophys Acta 200I, 1513:160-166.

32. Tay HK, Melendez Al: Fc $\gamma$-triggered generation of arachidonic acid and eicosaniods requires iPLA 2 but not CPLA in human monocytes. J Biol Chem 2004, 279:22505-225। 3 .

33. Akiba S, Hayama M, Sato T: Inhibition of $\mathrm{Ca}^{2+}$-independent phospholipase $A_{2}$ by bromoenol lactone attenuates prostaglandin generation induced by interleukin- IB and dibutyrly CAMP in rat mesangial cells. FEBS Lett 1998, 437:225-228.

34. Yan W, Jenkins CM, Han X, Mancuso DJ, Sims HF, Yang K, Gross RW: The highly selective production of 2-arachdonoyl lysophsphatidylcholine catalyzed by purified calcium-independent phospholipase $\mathbf{A}_{2 \gamma}$ J Biol Chem 2005, 280:26669-26679.

35. Ueno N, Murakami M, Tanioka T, Fujimori K, Tangbe T, Urade $Y$, Kudo I: Coupling between cyclooxygenase, terminal prostanoid synthase and phospholipase $\mathbf{A}_{2}$. J Biol Chem 200I, 276:349|8-34927.

36. Balsinde J, Balboa MA, Dennis EA: Functional coupling between secretory phospholipase $A_{2}$ and cyclooxygenase and its regulation by cytosolic group IV phospholipase. Biochemistry I998, 95:795I-7956.

37. Reddy ST, Winstead MV, Tischfield JA, Herschmann HR: Analysis of secretory phospholipase $A_{2}$ that mediate prostaglandin production in mast cells. J Biol Chem 1997, 272:13591-13596.

38. Arosh J, Banu SK, Chapdelaine P, Fortier MA: Temporal and tissue specific expression of prostaglandin receptors EP2, EP3, EP4, FP and cyclooxygenase $I$ and 2 in uterus and fetal membranes during bovine pregnancy. Endocrinology 2004, | 45:3076-309|.

39. Pratt BR, Butcher RL, Inskeep EK: Antiluteolytic effect of the conceptus and of $\mathrm{PGE}_{\mathbf{2}}$ in ewes. J Anim Sci 1995, 45:784-79I.

40. Arosh JA, Banu SK, Kimmins S, Chapdelaine P, MacLaren LA, Fortier $M A$ : Effect of interferon- $\tau$ on prostaglandin biosynthesis, transport, and signaling at the time of maternal recognition 
of pregnancy in cattle: evidence of polycrine actions of PGE. Endocrinology 2004, 145:5280-5293.

4I. Spencer TE, Ing NH, Ott TL, Mayes JS, Becker WC, Watson GH, Mirando MA, Bazer FW: Intrauterine injection of ovine interferon-tau alters oestrogen receptor and oxytocin receptor expression in the endometrium of cyclic ewes. J Mol Endocrinol 1995, I5:203-220.

42. Spencer TE, Bazer FW: Ovine interferon $\tau$ suppresses transcription of the estrogen receptor and oxytocin receptor in genes in the ovine endometrium. Endocrinology 1996, 137: I I44-I I 47.

43. Burgess KM, Ralph MM, Jenkins G, Thorburn GD: Effect of oxytocin and estradiol on uterine prostaglandin release in nonpregnant and early-pregnant ewes. Biol Reprod 1990, 42:822-833.

44. Mann GE, Payne JH, Lamming GE: Hormonal regulation of oxytocin-induced prostaglandin $F_{2 \alpha}$ secretion by the bovine and ovine uterus in vivo. Dom Anim Endo 200 I, 2I:I27-I4I.

Publish with Bio Med Central and every scientist can read your work free of charge

"BioMed Central will be the most significant development for disseminating the results of biomedical research in our lifetime. "

Sir Paul Nurse, Cancer Research UK

Your research papers will be:

- available free of charge to the entire biomedical community

- peer reviewed and published immediately upon acceptance

- cited in PubMed and archived on PubMed Central

- yours - you keep the copyright

Submit your manuscript here:

http://www.biomedcentral.com/info/publishing_adv.asp
BiolMedcentral 